\title{
An Instructional Design Framework to Improve Student Learning in a First-Year Engineering Class
}

\author{
Kumar Yelamarthi \\ School of Engineering and \\ Technology, \\ Central Michigan University, \\ Mt Pleasant, MI, USA \\ yelam1k@cmich.edu
}

\author{
Eron Drake \\ College of Medicine, \\ Central Michigan University, \\ Mt Pleasant, MI, USA
}

drake1ee@cmich.edu

\section{Matthew Prewett \\ Department of Psychology, Central Michigan University, Mt Pleasant, MI, USA}

prewe1ms@cmich.edu

\begin{abstract}
Increasingly, numerous universities have identified benefits of flipped learning environments and have been encouraging instructors to adapt such methodologies in their respective classrooms, at a time when departments are facing significant budget constraints. This article proposes an instructional design framework utilized to strategically enhance traditional flipped methodologies in a first-year engineering course, by using low-cost technology aids and proven pedagogical techniques to enhance student learning. Implemented in a first-year engineering course, this modified flipped model demonstrated an improved student awareness of essential engineering concepts and improved academic performance through collaborative and active learning activities, including flipped learning methodologies, without the need for expensive, formal active learning spaces. These findings have been validated through two studies and have shown similar results confirming that student learning is improved by the implementation of multi-pedagogical strategies informed by the use of an instructional design in a traditional classroom setting.
\end{abstract}

Keywords: collaborative learning; interactive learning environments; flipped classroom; instructional design

(CC BY-NC 4.0) This article is licensed to you under a Creative Commons AttributionNonCommercial 4.0 International License. When you copy and redistribute this paper in full or in part, you need to provide proper attribution to it to ensure that others can later locate this work (and to ensure that others do not accuse you of plagiarism). You may (and we encourage you to) adapt, remix, transform, and build upon the material for any non-commercial purposes. This license does not permit you to use this material for commercial purposes.

\section{Introduction}

In a fast-paced world where engineering concepts have been advancing rapidly, engineering instructors are under increased pressure to teach more concepts, increase student learning, and better prepare students for entering the professional world. In response, instructors have been exploring alternative teaching strategies, which include the utilization of flipped learning methods enhanced with technology 
tools or technology-rich active learning spaces. Currently, a popular method being adopted is a student-centered, active learning environment, where active learning is promoted through a collaborative and technology-rich, small-group setting, in which students work together on defined problems, while the teacher serves as the moderator (Singer, Nielsen, \& Schweingruber, 2012). In the sciences, this method of teaching is commonly referred to as "flipped," an instructional strategy where students view pre-recorded lecture content online prior to coming to the class. Class time is spent in discussions and problem-solving activities with the aid of technology-rich tools and equipment. One common characteristic of these newly adopted pedagogies is they reduce traditional lectures and foster active learning, engage students in self-directed learning, thus leading to increased academic success in science and engineering (Hong \& Shull, 2010; Vogt, 2008).

Yet, while studies on flipped learning models have demonstrated the significance and positive outcomes in student learning, engineering instructors have been relatively slow in adopting these flipped models into the classroom (Lodaya, 2013; Shelton, 2014). Some of the predominant reasons are that engineering education has been typically provided through a hands-on environment, often influenced by external stakeholders such as accreditation boards and professional organizations (Bishop \& Verleger, 2013). In addition, the cost of equipment and the appropriate preparation time to tailor course content dominates the adoption of technology-rich active learning classrooms (Cotner, Loper, Walker, \& Brooks, 2013). Additionally, relatively little literature exists in engineering education that presents an effective instructional design framework used to revise an existing traditional course (TC) to an effective flipped course (FC) that does not require extensive financial resources and/or active learning spaces. Thus, there exists a need among new engineering instructors for such a framework, as the majority of new instructors do not have appropriate experience and will typically replicate the instructional methodologies they experienced as learners (Lawler \& King, 2000; Visco \& Schaefer, 2015). Moreover, while flipped models are currently a popular pedagogical methodology, it is essential that instructors identify and align all factors critical to the design and delivery of effective learning environments to ensure and sustain student academic success.

The purpose of this paper is to present an instructional design framework, which can be utilized to effectively design and appropriately "flip" a first-year engineering course utilizing low-cost technology aids and proven pedagogical techniques, to improve student learning. By examining the situational factors, identifying course learning objectives, and ensuring alignment of instructional design elements, the proposed framework has demonstrated the ability to complete course content ahead of traditional schedule, increase course content, improve awareness to engineering applications, and improve student learning through a collaborative and engaging environment.

\section{Literature Review}

Engineering instructors have a variety of responsibilities related to teaching such as demonstrating disciplinary knowledge, interacting with and advising students, and organizing and delivering course content, to name a few. However, few instructors have extensive training on the "design of instruction" or creating an instructional design framework to inform the development of an effective learning environment (Fink, 2013). To assist instructors and help them learn how to design their courses more effectively, Fink (2013) developed an instructional design model that integrated and aligned important situational learning factors with learning goals, teaching and learning activities, and feedback and assessment methods. By using a "backward design" sequence developed by Wiggins (1998), Fink asserted that the successful design of a course began with clarifying learning goals and identifying how students would receive feedback and assessment data. This information would then assist instructors in determining which teaching and learning activities were most appropriate for the learning context. Other instructional design frameworks are similar and typically include purposeful connections between learning objectives, course organi- 
zation, learner tasks, instructor roles, student roles, technological tools, and assessment strategies (e.g., Koehler \& Mishra, 2008; Wiggins \& McTighe, 1998). Further, Reeves (2006) asserted that "alignment cannot be over-emphasized (p. 303) and recommended the alignment of the following factors as essential to the instructional design of a learning environment: (1) learning objectives, (2) nature of content, (3) course plan and organization, (4) learner tasks, (5) instructor roles, (6) student roles, (7) technological affordances, and (8) assessment strategies.

The learning environment or a course can be influenced by a variety of situational influences, such as institutional program or curricular goals as well as accreditation requirements. Specific to introductory engineering courses, historically, digital circuits and their respective theories have been taught to electrical and computer engineering students late in the engineering curriculum (Roppel, Hung, Wentworth, \& Hodel, 2000). An early exposure to these discrete mathematicsbased engineering concepts could promote a better understanding of fundamental computer science and engineering concepts. Further, using a computer or microcontroller as a device to control physical events is typically encountered in upper-level engineering courses (Canfield, Ghafoor, \& Abdelrahman, 2012). Therefore, it was recommend (Yelamarthi, \& Drake, 2015) that the engineering curriculum should change the sequencing in which programming is taught, moving it earlier in the program with less focus on syntax and notation, while increasing demonstrations of the relationships between a program statement and its impact on controlling the environment for a real-world application.

While frequently included as important situational factors in instructional design frameworks (Fink, 2013), instructor roles and student characteristics continue to dominate recent research. For example, several studies have demonstrated a strong relation between student performance and perception of faculty interactions (Hong \& Shull, 2010; Micari \& Pazos, 2012; Suresh, 2006; Vogt, 2008). Hong and Shull (2010) demonstrated that an absence of a positive relationship with faculty often left students being disheartened, leading to discouraged students, and thus high attrition rates. Micari and Pazos (2012) and Vogt (2008) have demonstrated that a positive relationship (approachability and respect for students) resulted in increased student confidence and perceived success in subsequent courses.

There are hundreds, if not thousands of teaching and learning methods, and significant research (Baepler, Walker. \& Driessen, 2014; Bishop, \& Vergler, 2013; Dal, 2013; Freeman, Eddy, McDonough, Smith, Okoroafor, Jordt, \& Wenderoth, 2014; Kim, Patrick, Srivastava, \& Law, 2014; Lodaya, 2013; Prince, 2004) has demonstrated that students learn better through active learning activities (e.g., hands-on design) over traditional lectures or methods. Specifically, engineering design activities must be developed with an emphasis on collaborative learning, relation to real-world scenarios, and build upon previous knowledge (Freeman et al., 2014; Hart Research Associates, 2015; Prince, 2004). The flipped or inverted classroom is one pedagogical model that has been proven to accommodate the integration of diverse active learning strategies with a focus on real-world scenarios. In brief, the flipped classroom utilizes technology (e.g., video or "web class," podcasts) to introduce students to course content outside of the classroom, so that students can engage in immersive classroom activities to deepen their level of understanding (Strayer, 2012). Emerging research indicates that students in an effectively designed flipped classroom become more aware of their learning, make connections to course content, and improve their performance (Koproske, 2012; Mason, Shuman, \& Cook, 2013; Strayer, 2012). In a study of an upper-division engineering course, researchers reported that teachers were able to cover more course content, implement active, cooperative, and problem-based learning activities into the classroom without sacrificing course content, and that students in a flipped classroom performed as well as or better on comparable quiz, exam, and design problems (Mason et al., 2013).

As a result of interest in flipped classroom methods, various strategies and technological tools have been developed or repurposed for classroom or educational use. One such strategy is lecture 
capture, which provides the ability to review segments of lectures, facilitate meaningful connections between consecutive lectures, obtain additional clarity of essential course content, make up for unavoidable time conflicts, and allow students to learn at their own pace (Nashash \& Gunn, 2013). However, this instructional strategy does not provide a deeper understanding of engineering concepts, which is typically obtained through interactive discussions and problem solving in a classroom (Felder, 2012). Addressing this, various pedagogical tools and methods have been adopted, such as interactive software (Ganago \& Liao, 2013), web-based materials (Danielson, Preast, Bender, \& Hassall, 2014; Rosa-Pohl, Long, \& Goodwin, 2013), and problem-based learning (Baepler et al., 2014; Berrett, 2012; Vignare, 2007).

Providing timely and relevant feedback to students on their academic progress is essential to the learning process and an important factor when designing effective instruction. Expert teachers consistently monitor the current status of student understanding (Hattie, 2012) and frequently seek student feedback data to update their respective instructional methods. This regular collection of data to inform the teaching effectiveness and learning progress is referred to as formative assessment, and both formative and summative assessments are recommended in effective course design. Although both formative and summative feedback and assessments are important components of instructional design, formative feedback when provided frequently, immediately, discriminatively (e.g., based on standards and criteria), and supportively, will motivate students to produce high-quality work (Bain, 2004).

Overall, numerous research studies have been published demonstrating the significance of diverse pedagogical instructional methods in engineering education. However, a majority of them do not utilize an instructional design framework to purposefully inform course design or redesign, primarily due to a lack of training or faculty development within the discipline, not to mention the extensive time commitment required from the faculty members to get accustomed to and design new instructional content. In acknowledgement and by way of addressing these challenges, this research paper presents the successful implementation of an instructional design framework, used to strategically identify and align instructional factors, including multiple pedagogical strategies that increased interest in engineering concepts and enhanced academic performance in a first-year engineering course at a public university.

\section{Redesign of an Existing Course Using an Instructional Design Framework}

As a result of the identification of challenges embedded within the sequencing of concepts in introductory engineering, the Digital Circuits (DC) course at a public university has been taken as a test platform for the low-cost modified flipped model presented next. This modified flipped course framework provides the opportunity to offer diverse learning experiences that support students' respective learning styles, while at the same time offers more time within the classroom to create positive student-faculty relationships, increased engagement on relevant assignments and projects, and relevant feedback on learning progress.

In the past, the DC course has been taught in the traditional manner with two 75-minute class sessions per week, with topics including Boolean algebra, logic function, truth tables, Karnaugh maps, combinational, and sequential circuits. While this course met the broad program objectives and electrical engineering (EE) students were able to relate the concepts to real-world applications, non-EE students were not able to realize the relevance for their respective curricula. With the overall goal of improving student learning, while limiting the required time commitment required from the instructor, the instructional course redesign process initiated with the following objectives: 
- Identify evidence-based, effective teaching strategies that increase student engagement and academic success both inside and outside of the classroom;

- Effectively align the course objectives, learning activities, and assessment metrics with a focus on reducing faculty preparation time, increasing student time on task, increasing student buy-in, and accommodating limitations in the physical class setting;

- Implement economical and efficient technology aids in the classroom;

- Identify ways to introduce and increase student awareness to diverse opportunities and challenges in engineering; and

- Implement simple, yet effective classroom assessment techniques to assess teaching effectiveness, and student learning.

Based on these objectives, a combination of course design models (Fink, 2013; Koehler \& Mish$\mathrm{ra}, 2008$ ) were used to formulate a three-step instructional design framework presented in Figure 1 , which include (i) examining situational factors that influence the instructional design of a course, (ii) formulating the student learning goals through course learning objectives (CLO), and (iii) ensuring alignment of CLOs with instructional design elements.

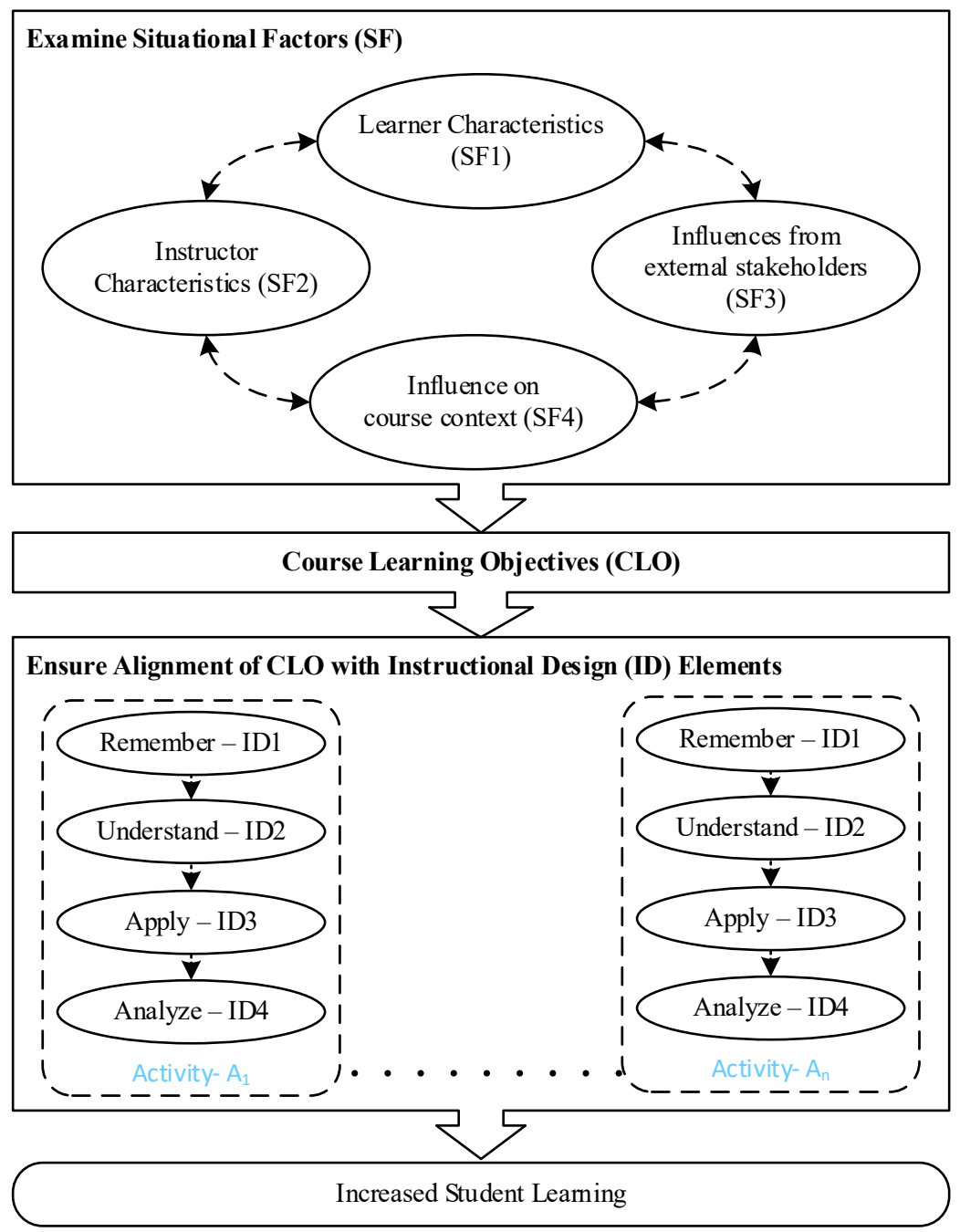

Figure 1. Instructional design framework for the modified flipped first-year DC course 
The situational factors in this course include learner (student) characteristics (SF1), instructor characteristics (SF2), influences from external stakeholders (SF3), and influences on the course context (SF4). While these situational factors might change with a different course, it is crucial to identify the interrelation between each, so as to help in the formulation of the CLOs. The identified learner characteristics include a required course for all incoming first-year engineering students, a lack of programming expertise, and a lack of prior knowledge of calculus. Further, as a first-year course, it is also vital to increase student-faculty rapport, awareness to real-world challenges, and engage students in hands-on based design activities through collaborative activities. The instructor characteristics identified include expert knowledge related to the subject matter, a level of competence and confidence with effective teaching and learning strategies, and experience and attitudes toward the implementation of technological learning tools. Further, the identified influences from external stakeholders included accreditation requirements, recommendations from related professional organizations, and challenges related to retaining first-year engineering students. Finally, influencers related to course context were class sizes of 25-40 students, introductory level of the course, two 75-minute class sessions per week, space availability for group activities, access to computers, and a learning management system (e.g., Blackboard).

Typically, first-year engineering students take a series of mathematics and other courses to acquire the knowledge and skills necessary for them to be able to complete engineering projects. The consequent long delay between their entering an engineering program and having the opportunity to apply content knowledge to a meaningful technical project has a negative impact on their enthusiasm, motivation, and retention in the program (Rosa-Pohl et al., 2013). Addressing this challenge, several engineering instructors have updated their curricula so as to engage students in hands-on design projects in the first-year curriculum. While this method potentially keeps students motivated, finding a project that first-year students can successfully complete is often difficult, due to their limited engineering knowledge and skills. The DC course requires transferable skills such as critical thinking and problem solving, but not advanced knowledge in calculus.

Implementing the sequencing of "backward design" (Wiggins \& McTighe, 1998), the instructional design process continued by examining the interrelation between situational factors, and the initial CLOs presented in Table 1. Upon examination of situational factors, CLOs, and expectations for competencies required for graduating engineering students, the course was updated to increase active and collaborative learning activities; integrate relevant concepts, and applications; increase opportunities for student learning and motivation; increate student-faculty interactions, provide timely and relevant feedback; and offer diverse opportunities to increase content knowledge. Specific learning and feedback activities were selected based on their "high" or "medium" effect on student academic performance as examined by Hattie (2012) in his meta-analysis of over 900 research studies. As a result of this instructional design process, the CLOs were updated as presented in Table 2.

Table 1. Initial Course Learning Objectives for Digital Circuits Course

\begin{tabular}{|cl|}
\hline No & \multicolumn{1}{c|}{ Course Learning Objective (CLO) } \\
\hline CLO-1 & Convert a number between different number systems \\
CLO-2 & Perform arithmetic operations using binary, octal, and hexadecimal numbers \\
CLO-3 & Describe the operation of logic gates \\
CLO-4 & Perform gate-level minimization \\
CLO-5 & Design and optimize simple combinational and synchronous sequential logic circuits \\
CLO-6 & Identify current and future applications of digital circuits \\
\hline
\end{tabular}


Active and collaborative learning strategies, including flipped methodologies and the use of technological aids and tools, were strategically selected and implemented to enhance student understanding of engineering design concepts. Specifically, each hands-on design activity class was designed to follow four steps: (i) remember: recall knowledge from memory or previous activity; (ii) understand: construct meaning from concepts learned; (iii) apply: execute a procedure based on understood concepts; and (iv) analyze: break concepts into parts, determine how each part relate to one another for a purpose, as adapted from Bloom's revised taxonomy (Krathwohl, 2002), All primary design activities in this multi-pedagogical model have been designed to follow these four steps while aligning with the CLOs as presented in Table 2.

Table 2. Updated Course Learning Objectives per the instructional design framework

\begin{tabular}{|rl|}
\hline No & \multicolumn{1}{c|}{ Course Learning Objective (CLO) } \\
\hline CLO-1 & Convert a number between different number systems \\
CLO-2 & Perform arithmetic operations using binary, octal, and hexadecimal numbers \\
CLO-3 & Describe the operation of logic gates \\
CLO-4 & Perform gate-level minimization \\
CLO-5 & Design and optimize simple combinational and synchronous sequential logic circuits \\
CLO-6 & $\begin{array}{l}\text { Identify current and future applications of digital circuits } \\
\text { CLO-7 }\end{array}$ \\
CLO-8 & $\begin{array}{l}\text { Implement digital circuits using electrical laboratory procedures } \\
\text { them, through practical applications }\end{array}$ \\
CLO-9 & $\begin{array}{l}\text { Control digital systems using basic programming structures such as loops, conditionals, and } \\
\text { functions }\end{array}$ \\
CLO-10 & $\begin{array}{l}\text { Demonstrate critical thinking and problem-solving skills in team-based hands-on engineering } \\
\text { activities. }\end{array}$
\end{tabular}

Unlike much of the technology-rich, active learning classrooms that are currently being built around the country at costs often exceeding a million dollars (Smith, 2015), the presented model has been easily and effectively implemented in a traditional classroom without formally designed active learning spaces. In addition to inexpensive utilization of classroom space, the cost for resources for the instructor has also been minimal. The only additional technology aids used by the instructor were a trackpad to write and record problems and its solutions, such as a Bamboo Capture Pad (www.wacom.com), and screen casting software, such as Camtasia (https://www.techsmith.com/camtasia.html).

\section{Course Implementation}

This study utilized nonequivalent groups involving undergraduate students across multiple semesters. Assessment of the course included three course examinations and student perception surveys. Students in the first control group (Control-01) attended class twice a week ( 75 minutes each session) in a traditional classroom, where they were seated in a traditional theater style. They listened to lectures, watched a few live demonstrations, and answered questions from the instructor. During the following year, the first experimental group (Experimental-01) attended class twice a week ( 75 minutes each time) in a traditional classroom, but with updated seating style (small groups of four to five students) to reinforce teamwork and group problem solving. They had access to an online preview of lectures, solved problems in small groups during class, worked with computer simulations, participated in hands-on design activities, and answered ques- 
tions from the instructor as a team. In order to validate the positive impact this course has had on student learning, this study was repeated on a second control group (Control-02) and second experimental group (Experimental-02) as presented in Figure 2.

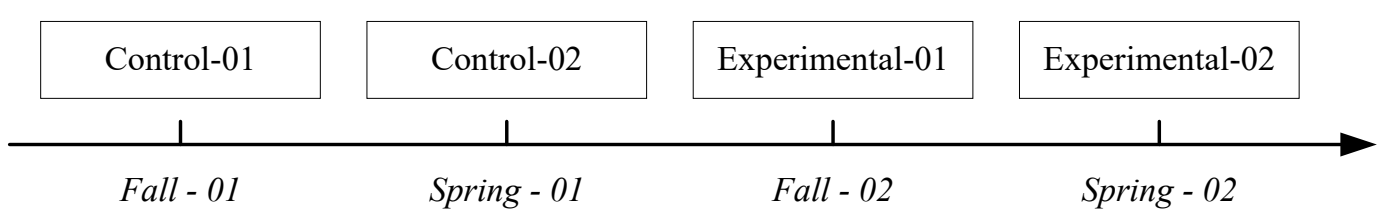

Figure 2. Timeline of presented research study

Participants in this study include all students in four sections of Engineering (EGR) 190 Digital Circuits in two consecutive academic years. Due to the open enrollment policy of the university, no specific recruitment strategy was used in any of the groups, and students self-selected themselves into the class. During the first class session, students in the experimental groups were provided the opportunity to opt out of the study, or move to a different section taught in the traditional model; however, none chose this option. All students in the experimental group were surveyed during the mid- and end-of-semester by an external evaluator. The research design and assessment instruments were approved by the university's institutional review board. Student grade data was collected from the instructor while their demographic data was collected from the university's Office of Institutional Research. One hundred twenty students participated in this study.

\section{Traditional Model}

During the first academic year, the DC course was taught to two control groups (control-01, control-02) in the traditional model. In each 75-minute class session, the instructor taught concepts using PowerPoint slides, solved problems on a whiteboard, while students took notes. Occasionally, students were asked to solve problems on their own, with the instructor walking around the classroom to monitor student progress, and provided individual feedback. Most problems solved during class were drawn from the textbook and weekly homework constituted of handwritten problems. Students did not have access to any online videos or online quizzes. Hands-on design activities on the course concepts were introduced in a subsequent course.

\section{Modified Flipped Model}

During the second academic year, the DC course was offered to two experimental groups (experimental-01, experimental-02) in the modified flipped model. Students met twice a week in a traditional classroom with no formal active learning spaces, with each session lasting 75 -minutes. The instructor used several pedagogical methods, including active and collaborative learning strategies infused through all in-class activities, and critical thinking strategies through all inside and outside class activities. The instructor organized all educational activities in the classroom such as preparing pre-lecture videos, delivering lectures during class, forming student groups, providing timely student feedback, and directing the students to engage in hands-on design activities.

To encourage self-directed learning and provide quality in-class time with a focus on application and analysis, prior to attending each class, students were required to watch two or three videos (one or two pre-lecture previews, one Technology-Entertainment-Design (TED) talk) with a total maximum duration of 30 minutes. These pre-lecture previews (audio recording of instructor's voice and video capture of a tablet screen) served as the first means of disseminating course material (Mason et al., 2013) and provided a preview of course concepts through schematics, equations, and tables to engage engineering students, and provided a pre-exposure for quicker learning 
(Jensen, 2008). To demonstrate the significance of engineering, students were also asked to watch one specific TED talk (TED, 2016) each week. All these videos were made available to students at least ten days before the class. Upon completion, students completed a short (five question) pre-lecture quiz 24 hours prior to the lecture, to help the instructor assess their preliminary understanding. Scores from this pre-lecture quiz were used to obtain just-in-time feedback and identify concepts that were difficult for the students. This provided an opportunity for the instructor to update the classroom interactive content for active discussions and facilitate a deeper synthesis of course concepts during the class period.

The diverse nature of in-class activities to promote active and collaborative learning during the 75-minute class session is represented in Figure 3. The first 10 minutes were utilized to reflect on the assigned TED talk, including but not limited to the following: applications of circuits; the theory behind the operation of a transistor; technical challenges in the design and implementation of a flapping wing aerial robot; open and closed loop control systems; crowd-sourced fundraising; autonomous self-driving cars; miniature energy harvesters; self-aware robots; and classes where concepts behind each topic would be taught in their respective curriculum. These discussions served as icebreakers, demonstrating the importance of engineers on the community at large, increasing students' awareness of engineering career opportunities, and reinforcing their critical thinking skills. The next five minutes were used to briefly reflect on what students had learned during the previous class and answer any questions. This brief reflection formed an effective bridge from prior knowledge to new knowledge, as students learned new topics, thus aiding in the retention of key concepts (Jensen, 2008). The next 50-55 minutes were used to engage students in active learning through individual and group problem solving, demonstrations, and hands-on based design activities. The last five to ten minutes were used reflect on what students have learned and identify one concept that requires further clarification, which was revisited in the following class session. This sequence of learning activities, as presented in Figure 4, was very effective and each activity furthered learning acquisition in a logical fashion, increasing content knowledge and retention.

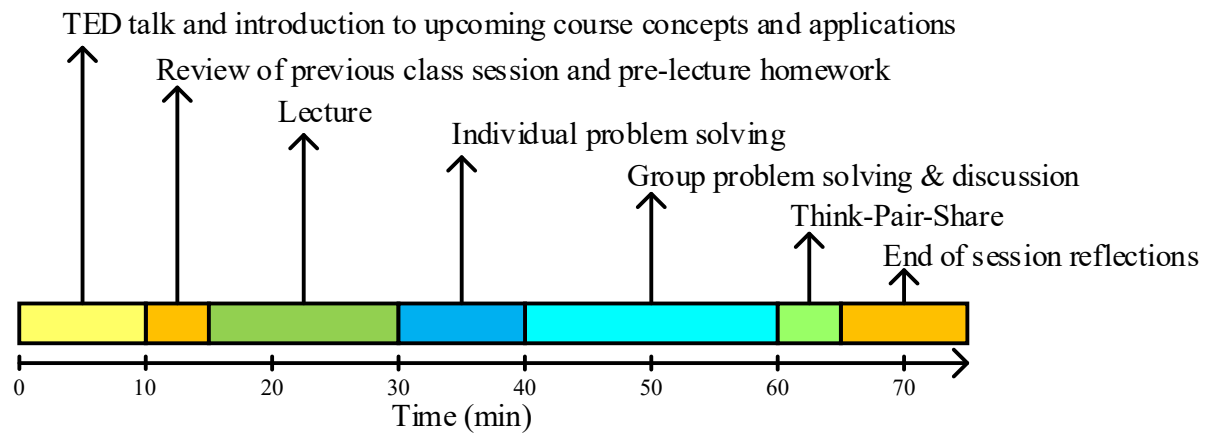

Figure 3. In-class activities during a typical 75-minute session in the flipped model

The utilization of an instructional design framework requires an on-going iterative process to monitor and ensure course redesign and its alignment with instructional design elements. Figure 4 provides an outline of all learning and assessment activities in the modified flipped model, as aligned with the instructional design framework elements in Figure 1. The resulting combination of in-class and outside-of-class activities and assessments aligned with the situational factors (SF 1-4), CLOs, and instructional design elements (ID 1-4), enabled the instructor the ability to easily monitor student engagement, provide opportunities for increased learning, offer timely and relevant feedback, and assess student progress toward the attainment of CLOs. 


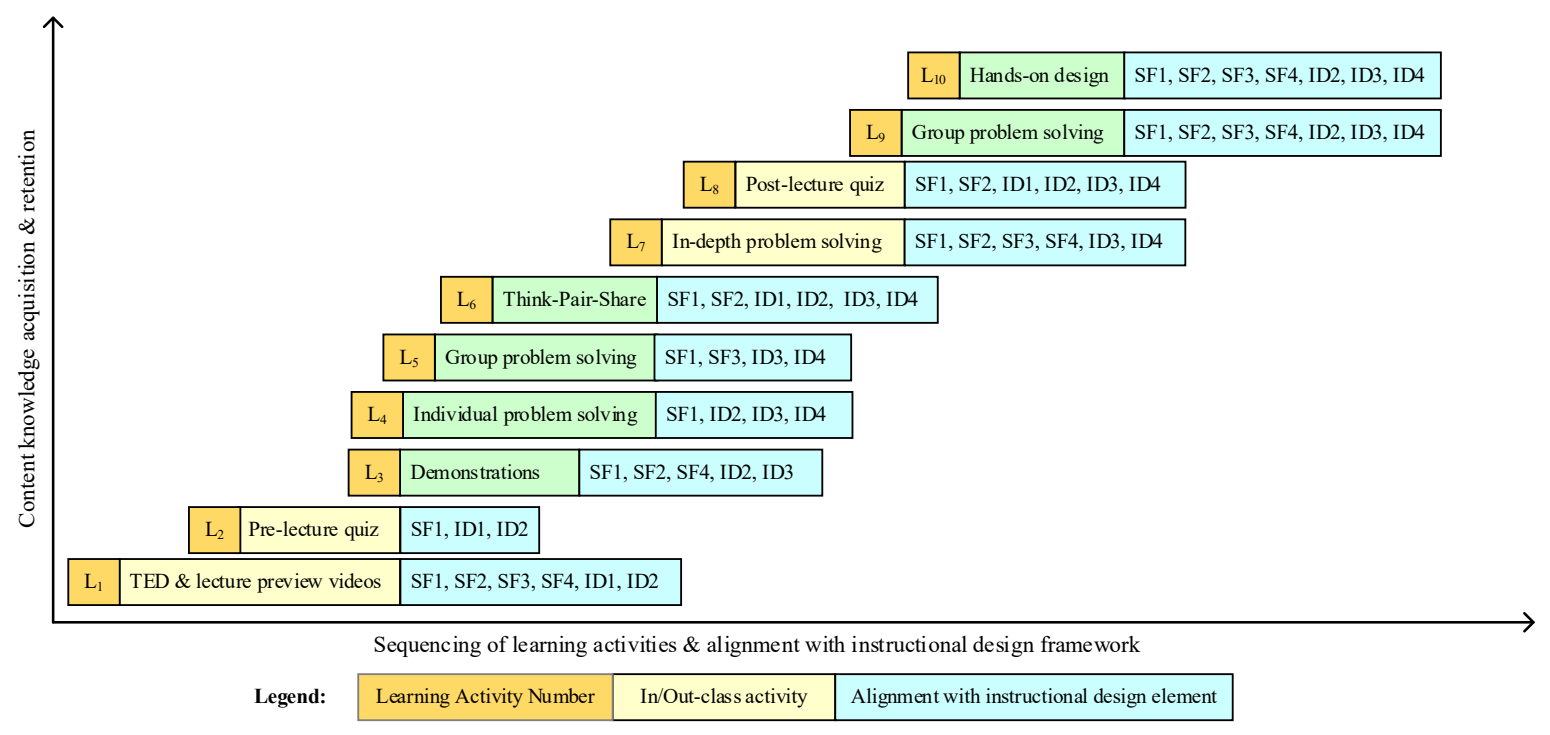

\section{Figure 4. Learning activities sequence and alignment with instructional design framework in the modified flipped model}

More specifically, the in-class learning activities were designed and monitored to align with CLOs and instructional design elements as presented in Table 3. The first design activity (A1) of circuit simulation in a seatbelt warning system was used to introduce students to design and verification. With the foundational knowledge of such system, students identified the different logic gates necessary, understood the interaction between each gate through simulation, and analyzed how logic gates could be used to solve real-world problems. Building on this, in the second design activity (A2) students identified the test equipment, learned its operation, read circuit datasheets to identify pin configuration, built and verified its operation. This process helped them understand similarities between simulation and physical circuit design, and helped them analyze the difference in test procedures. During the third design activity (A3), they built a circuit of a railyard switch, analyzed its transient properties, and documented the difference between theoretical and practical outcomes. Building upon this principle of incremental learning, the next two design activities involved the design of a lawn sprinkler controller logic and its respective automation.

The sixth design activity (A6) required students to design and implement a humidity monitoring system for a pathogen handling facility using a microcontroller, sensors, and actuators. Students were provided the theoretical foundation, hardware components, circuit schematic, and a skeleton program. Later, they were taught to build a temperature monitoring system and update it to monitor temperature and humidity at periodic intervals. This activity taught interfacing sensors with a microcontroller, relation between programming constructs such as while loops, delay statements, and frequency of operation. The next design activity (A7) focused on upgrading the previous system to include unauthorized entry detection and alarm capability. During this activity, students learned the principles behind the operation of an infrared sensor, audio speaker, and programming constructors such as variables, user-defined functions, and fundamental numerical analysis.

The last design activity (A8) was designed to demonstrate the integration of different circuit elements such as logic gates, resistors, LEDs, microcontroller, ultrasonic sensor, servo motor, and a miniature speaker to solve a problem that emulates a real-world scenario. In this activity, students were instructed to design an automated security system with the following criteria: 
i. Hide the weapon system when no intruder is detected.

ii. Inform key personnel when an unauthorized entry is detected within a distance of $1 \mathrm{~m}$.

iii. Engage the weapon system upon authorization from three key personnel and presence of unauthorized entry.

iv. Vary alarm intensity with respect to the distance of intruder.

v. In addition to power supply pins, only two analog pins of the microcontroller can be used to verify criteria-ii.

vi. In addition to the power supply pins, only two output pins can be used to engage the missile system and alarm.

Table 3. In-class design activities in the modified flipped course

\begin{tabular}{|c|c|c|c|c|c|c|}
\hline $\begin{array}{c}\text { Design } \\
\text { Activity } \\
\#\end{array}$ & Activity & Remember & Understand & Apply & Analyze & CLO \\
\hline A1 & $\begin{array}{l}\text { Circuit Simu- } \\
\text { lation - seat- } \\
\text { belt warning } \\
\text { system }\end{array}$ & $\begin{array}{l}\text { Concept of design } \\
\text { and verification }\end{array}$ & $\begin{array}{l}\text { Interaction be- } \\
\text { tween logic gates } \\
\text { through simula- } \\
\text { tion }\end{array}$ & $\begin{array}{l}\text { Circuit simula- } \\
\text { tion software to } \\
\text { verify circuit } \\
\text { operation }\end{array}$ & $\begin{array}{l}\text { How logic gates } \\
\text { work together to } \\
\text { solve real-world } \\
\text { problem }\end{array}$ & $\begin{array}{l}1,2 \\
3,10\end{array}$ \\
\hline $\mathrm{A} 2$ & $\begin{array}{l}\text { Circuit De- } \\
\text { sign - seatbelt } \\
\text { warning sys- } \\
\text { tem }\end{array}$ & $\begin{array}{l}\text { Circuit design } \\
\text { components and } \\
\text { test equipment }\end{array}$ & $\begin{array}{l}\text { Similarities be- } \\
\text { tween simulation } \\
\text { and physical cir- } \\
\text { cuit operation }\end{array}$ & $\begin{array}{l}\text { Knowledge of } \\
\text { physical circuit } \\
\text { elements to build } \\
\text { a system }\end{array}$ & $\begin{array}{l}\text { The difference in } \\
\text { test procedure } \\
\text { between simula- } \\
\text { tion and physical } \\
\text { circuit }\end{array}$ & $\begin{array}{c}3,4 \\
6,7 \\
10\end{array}$ \\
\hline A3 & $\begin{array}{l}\text { Circuit De- } \\
\text { sign - railyard } \\
\text { switch }\end{array}$ & $\begin{array}{l}\text { Operation of a } \\
\text { railyard switch }\end{array}$ & $\begin{array}{l}\text { Transient proper- } \\
\text { ties of logic gates }\end{array}$ & $\begin{array}{l}\text { Build logic cir- } \\
\text { cuits to reduce } \\
\text { circuit delay }\end{array}$ & $\begin{array}{l}\text { Transient proper- } \\
\text { ties of logic cir- } \\
\text { cuits for perfor- } \\
\text { mance estimation }\end{array}$ & $\begin{array}{l}3,4 \\
5,6 \\
7,10\end{array}$ \\
\hline A4 & $\begin{array}{l}\text { Circuit De- } \\
\text { sign -lawn } \\
\text { sprinkler } \\
\text { system }\end{array}$ & $\begin{array}{l}\text { Application of } \\
\text { digital circuit } \\
\text { blocks - decoders }\end{array}$ & $\begin{array}{l}\text { Gate-level mini- } \\
\text { mization to simp- } \\
\text { ly logic circuit }\end{array}$ & $\begin{array}{l}\text { Connect circuit } \\
\text { elements to build } \\
\text { a functional } \\
\text { household sys- } \\
\text { tem }\end{array}$ & $\begin{array}{l}\text { Circuit architec- } \\
\text { ture for perfor- } \\
\text { mance improve- } \\
\text { ment }\end{array}$ & $\begin{array}{c}4,5 \\
6,7 \\
10\end{array}$ \\
\hline A5 & $\begin{array}{l}\text { Circuit De- } \\
\text { sign - Auto- } \\
\text { mated lawn } \\
\text { sprinkler } \\
\text { system }\end{array}$ & $\begin{array}{l}\text { Need to automate } \\
\text { a digital system }\end{array}$ & $\begin{array}{l}\text { How pre-existing } \\
\text { designs can be } \\
\text { improved for } \\
\text { performance }\end{array}$ & $\begin{array}{l}\text { Integrate combi- } \\
\text { national logic } \\
\text { circuits with } \\
\text { memory ele- } \\
\text { ments }\end{array}$ & $\begin{array}{l}\text { Operation of } \\
\text { memory elements }\end{array}$ & $\begin{array}{l}3,4 \\
5,6 \\
7,10\end{array}$ \\
\hline A6 & $\begin{array}{l}\text { System De- } \\
\text { sign - Hu- } \\
\text { midity Moni- } \\
\text { toring }\end{array}$ & $\begin{array}{l}\text { Need for sensors } \\
\text { and microcontrol- } \\
\text { lers }\end{array}$ & $\begin{array}{l}\text { Interaction be- } \\
\text { tween logic gates } \\
\text { and microcontrol- } \\
\text { ler }\end{array}$ & $\begin{array}{l}\text { Make use of } \\
\text { sensors \& sys- } \\
\text { tems to monitor } \\
\text { environment }\end{array}$ & $\begin{array}{l}\text { Impact of pro- } \\
\text { gramming state- } \\
\text { ments on real- } \\
\text { world }\end{array}$ & $\begin{array}{c}6,7 \\
8,9 \\
10\end{array}$ \\
\hline A7 & $\begin{array}{l}\text { System De- } \\
\text { sign - Alarm } \\
\text { system }\end{array}$ & $\begin{array}{l}\text { Necessity for } \\
\text { closed-loop sys- } \\
\text { tems }\end{array}$ & $\begin{array}{l}\text { Relation between } \\
\text { programming } \\
\text { constructs and } \\
\text { real-time opera- } \\
\text { tion }\end{array}$ & $\begin{array}{l}\text { Design \& im- } \\
\text { plement an au- } \\
\text { tomated intruder } \\
\text { alert system }\end{array}$ & $\begin{array}{l}\text { Relation between } \\
\text { logic expressions } \\
\text { and physical } \\
\text { movement }\end{array}$ & $\begin{array}{c}6,7 \\
8,9 \\
10\end{array}$ \\
\hline A8 & $\begin{array}{l}\text { System De- } \\
\text { sign - Auto- } \\
\text { mated securi- } \\
\text { ty system }\end{array}$ & $\begin{array}{l}\text { How multiple } \\
\text { concepts can be } \\
\text { combined to solve } \\
\text { a problem }\end{array}$ & $\begin{array}{l}\text { How various sub- } \\
\text { systems collabo- } \\
\text { rate to solve a } \\
\text { larger problem }\end{array}$ & $\begin{array}{l}\text { Automate the } \\
\text { security system }\end{array}$ & $\begin{array}{l}\text { Relation between } \\
\text { functions and } \\
\text { subroutines in a } \\
\text { computer pro- } \\
\text { gram }\end{array}$ & $\begin{array}{c}6,7 \\
8,9 \\
10\end{array}$ \\
\hline
\end{tabular}


This activity taught students how to integrate different systems, basics of analog to digital conversion through calibration of the ultrasonic sensor, digital-to-analog conversion to play an alarm tune on a speaker, relation between program statements and their respective impact on the environment, and interfacing logic gates to microcontrollers. Through working to solve a real-world problem, students appeared particularly engaged in this activity. Anecdotally, they appeared to display a sense of pride after successfully completing this activity. After each class session, students took a post-lecture quiz on Blackboard (www.blackboard.com), where they were assessed on their conceptual knowledge acquisition and retention. This quiz proved to be timely and helpful as students were able to obtain instant feedback, and the instructor was able to assess student learning before the next class session. Further, this timely assessment of student learning helped the instructor identify difficult concepts for the students and customize the next session. Overall, this methodical educational process helped the instructor use class time effectively, reinforced student learning, and actively engaged and maintained student interest throughout class sessions.

\section{Methods}

The effectiveness of the modified flipped model was evaluated by comparing the achievement of CLOs, student performance in exams, and their perceptions of teaching, learning, and instructional methods. To measure student subject matter learning, students in the control and experimental groups completed two midterm exams and one final exam. The exams in these class offerings were constructed using multiple-choice and true-or-false questions that aligned with prior problems solved during pre- and post-lecture quizzes, open-ended problems, and circuit design questions, in alignment with the CLOs. Grading rubrics were used for all exams and were completed by the same instructor to ensure consistency. First, a comparison of average student scores and trend (incline or decline) of scores among midterm and final exam was used. Later, to identify statistical significance, statistical analyses (per Sahin \& Isler, 2013) were performed on the student grades. As several different measures of student learning and outcomes were collected, a two-factor multivariate analysis of variance (MANOVA) was conducted, with the teaching model (modified flipped vs. traditional) as the first factor and the semester (fall vs. spring) as the second factor. Semester was entered as a factor to control for any differences that may occur between different classes. A MANOVA provides an omnibus test of the factors on all outcomes at once, to limit the number of tests being conducted and thus limit the family-wise Type 1 error rate. After the MANOVA, a series of univariate (ANOVA) analyses were then conducted to determine if the teaching method influences all outcomes or if the overall effect was primarily driven by one exam. To further evaluate the effectiveness of the modified flipped model, student performance among both models was evaluated and compared by taking several problems from midterm and final exam as they relate the course objectives. This analysis provided information as to which CLOs has the highest impact and which CLO required additional emphasis in the instructional approach.

In addition, formative assessments were also conducted. As it is vital to identify which of the instructional methods were effective and which required additional enhancement, timely student reflections were necessary. Accordingly, five weeks into the semester and after the first midterm examination, students were formed into small focus groups and asked to collectively reflect on the strengths and weakness of the model. During this activity, students were asked to specify examples of each element to help the instructor better understand student perceptions of learning and to inform the effectiveness of instructional strategies. Further, students were asked to complete a brief individual survey to identify the effect of each instructional design element in the course. This survey was repeated at end of the semester to identify if there was a positive or negative effect over the semester. These surveys were designed to understand student perceptions of the degree to which the modified flipped model (1) promoted engagement, (2) improved learning experience, (3) used technology to promote learning, (4) enhanced ability to extrapolate learning 
to other subjects, (5) allowed flexibility in approaches to learning, and (6) facilitated competence with key learning outcomes. Scale reliability for this survey was assessed using Cronbach's alpha, which provides an estimate of internal consistency among the items. The resulting reliability coefficients were acceptable for both the first $(\alpha=.81)$ and the second $(\alpha=.87)$ survey.

As continual evaluation and assessment of each instructional activity are important, after each design activity, students were asked to reflect on their respective learning and extrapolate theoretical concepts. This was done to identify students' critical thinking and problem-solving skills, share their analysis with other students, and obtain feedback from the instructor. Lastly, to identify students' perceptions of the instructor, a brief student opinion survey was conducted at end of the semester. This survey was designed to evaluate instructor characteristics such as respect for student, accessibility to students, course organization, presentation of course material, instructor preparedness, and enthusiasm about the subject matter. The survey instruments used in this course are presented in the appendix, and their respective findings and analysis are presented in the next section.

\section{Results}

\section{Student Exam Performance}

A comparison of student performance between the traditional and multiple-pedagogical models is shown in Figure 5 for both study- 01 and study-02. The average of all three exams and the students' overall grades were higher when the course was offered in the multiple-pedagogical method. The more impressive finding is the reduced distribution in the range (the difference between maximum and minimum), indicating improvement in overall student performance.

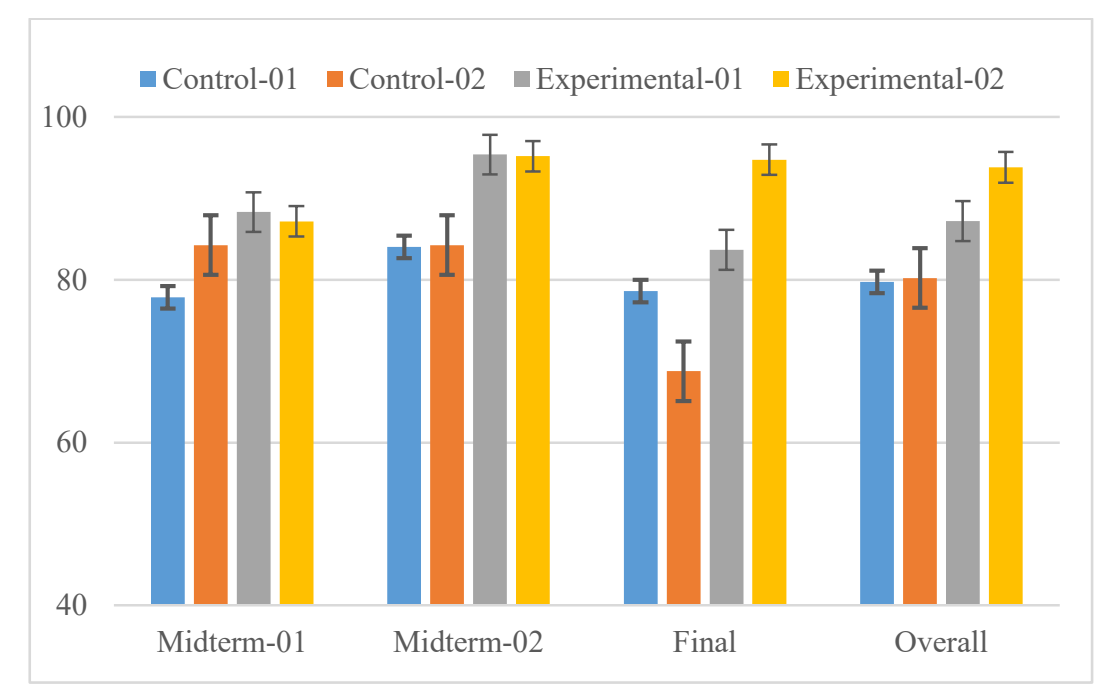

Figure 5. Comparison of student exam performance in both studies

The multivariate and univariate analysis results presented in Table 4 indicated significant differences on all student outcome measures between the teaching methods used, whereas there were no significant differences between semesters. Across all outcomes, the teaching method accounted for about $38 \%\left(\eta^{2}\right)$ of the variance in student exam scores; this effect was particularly strong for exams presented later in the semester (midterm 2 and the final exam). Semester, on the other hand, only accounted for about $3 \%$ of student scores. Interestingly, there was also an interaction between the teaching method and the semester, which was primarily driven by scores on the final exam. Although the modified flipped sections had higher final exam scores than the traditional sections for the fall and spring semester, this difference between sections was larger for the spring 
semester than for the fall semester. In conclusion, these results provide evidence that the modified flipped model can significantly improve student scores, though the magnitude of this improvement may vary from course to course. These findings are consistent or better than those reported in other research studies (Dal, 2013; Mason et al., 2013; Prince, 2004; Reisslein, Tylavsky, Matar, Seeling, \& Reisslein, 2007; Zappe, Leicht, Messner, Litzinger, \& Lee, 2009).

Table 4. Multivariate and Univariate Analysis on the Effect of Teaching Method and Semester on Student Performance

\begin{tabular}{|c|c|c|c|c|}
\hline Variable & F-ratio & df & p-value & Partial $\eta^{2}$ \\
\hline Teaching Method & 18.06 & 3,88 & $<.001$ & .381 \\
\hline Midterm $1^{\mathrm{b}}$ & 11.27 & 1,90 & .001 & .111 \\
\hline Midterm $2^{\mathrm{b}}$ & 26.27 & 1,90 & $<.001$ & .226 \\
\hline Final $^{\mathrm{b}}$ & 47.57 & 1,90 & $<.001$ & .346 \\
\hline Overall $^{\mathrm{b}}$ & 46.26 & 1,90 & $<.001$ & .339 \\
\hline Semester $^{\mathrm{a}}$ & 0.81 & 3,88 & .495 & .027 \\
\hline Midterm $1^{\mathrm{b}}$ & 1.98 & 1,90 & .163 & .022 \\
\hline Midterm $2^{\mathrm{b}}$ & 0.02 & 1,90 & .881 & .000 \\
\hline Final $^{\mathrm{b}}$ & 0.07 & 1,90 & .796 & .001 \\
\hline Overall $^{\mathrm{b}}$ & 0.43 & 1,90 & .513 & .005 \\
\hline Interaction $^{\mathrm{a}}$ & 11.86 & 3,88 & $<.001$ & .288 \\
\hline Midterm $1^{\mathrm{b}}$ & 2.70 & 1,90 & .104 & .029 \\
\hline Midterm $2^{\mathrm{b}}$ & 0.07 & 1,90 & .789 & .001 \\
\hline Final $^{b}$ & 21.51 & 1,90 & $<.001$ & .193 \\
\hline Overall $^{\mathrm{b}}$ & 1.70 & 1,90 & .196 & .019 \\
\hline
\end{tabular}

${ }^{\mathrm{a}}$ Results from two-factor MANOVA on all outcomes

${ }^{\mathrm{b}}$ Results from two-factor ANOVA on each outcome

To further evaluate the effectiveness of the modified flipped model, student performance was compared and grouped by the common CLOs in Table 5. While there is no profound difference in mean scores for CLO-1 and CLO-2, students' in the experimental group performed better for CLOs 3, 4, 5, and 6. The modified flipped model allowed for reinforcement of concepts through hands-on activities, with an emphasis on students identifying diverse applications of each concept. Accordingly, in addition to being able to solve problems as in the control group, students in the experimental group were able to reinforce their critical thinking and problem-solving skills in a collaborative environment, as evident through better mean scores in CLOs 3-6.

One of the advantages of presented modified flipped model is the ability to increase course content beyond what is offered in the traditional format. As it is equally important to assess achievement of CLOs for this new content, data in Table 6 presents this evidence through achievement of new CLOs 7-10. The mean scores for CLO 7-10 exhibit that students were able to identify applications of digital circuits, implement them using electrical laboratory procedures, and interface logic gates with microcontrollers, sensors, and actuators. 
Table 5. Comparison of student performance by CLOs

\begin{tabular}{|c|c|c|c|}
\hline $\begin{array}{c}\text { CLO (Prob- } \\
\text { lem No.) }\end{array}$ & $\begin{array}{c}\text { Control - } \\
\text { Mean }\end{array}$ & $\begin{array}{c}\text { Experimental } \\
- \text { Mean }\end{array}$ & Difference \\
\hline CLO-1 (1) & 83.7 & 89.4 & 5.7 \\
\hline CLO-2 (1) & 89.6 & 93.2 & 3.6 \\
CLO-2 (2) & 83.4 & 90.2 & 6.8 \\
\hline CLO-3 (1) & 93.2 & 97.6 & 4.4 \\
CLO-3 (2) & 76.7 & 94.3 & 17.6 \\
\hline CLO-4 (1) & 87.3 & 93.2 & 5.9 \\
CLO-4 (2) & 65.2 & 89.3 & 24.1 \\
\hline CLO-5 (1) & 73.7 & 85.3 & 11.6 \\
CLO-5 (2) & 78.2 & 87.6 & 9.4 \\
\hline CLO-6 (1) & 76.7 & 94.3 & 17.6 \\
CLO-6 (2) & 78.8 & 91.3 & 12.5 \\
\hline
\end{tabular}

Table 6. Student performance of new CLOs in experimental group

\begin{tabular}{|c|c|}
\hline CLO (Problem) & Mean \\
\hline CLO-7 (1) & 85.1 \\
CLO-7 (2) & 98.3 \\
\hline CLO-8 (1) & 88.6 \\
CLO-8 (2) & 92.0 \\
\hline CLO-9 (1) & 93.7 \\
CLO-9 (2) & 92.3 \\
\hline CLO-10 (1) & 85.1 \\
CLO-10 (2) & 91.6 \\
\hline
\end{tabular}

In addition, after each design activity, student groups in the experimental groups were asked to reflect on their respective learning and extrapolate theoretical concepts by identifying engineering applications as presented in Table 7 and Table 8. These student responses show that they had a good understanding of the underlying DC concepts, were able to solve emulated real-world problems, and reinforce their critical thinking and problem-solving skills. The diverse instructional methods combined with prompt student feedback helped to achieve this improved student performance. Further, the collaborative activities provided opportunities for enhanced critical thinking and problem-solving skills essential in engineering (Koproske, 2012). Overall, this quantitative assessment of student performance clearly demonstrates the positive influence on student learning and academic success through the presented modified flipped model. 
Table 7. Student Reflections on Learning from Experimental Groups

[I learned] how to connect different digital circuit components together and verify their operation Learned the significance of digital circuits for different applications

I learned how loops in programming work

... I learned how to program and integrate multiple programs as applicable for devices we use in everyday lives...

Sensors can be combined to make useful devices for many situations...

[I learned] how to change a program from doing one activity a certain way to do it another way

[I learned] how to debug a program for errors and fix them to assure proper operation

I learned more about using microcontrollers with other inputs and outputs and programs

We do not need a large computer to solve simple problems

[I learned] how to combine logic gates, sensors, actuators, microcontrollers to create a closed-loop alarm system

[I learned that] different engineers work in teams to solve problems

[I learned] the difference between open-loop and closed-loop systems

[I learned about] different careers I can pursue upon graduation

Table 8. Student Responses to Applications of Digital Circuits from Experimental Groups

\begin{tabular}{|l|l|}
\hline \multicolumn{1}{|c|}{ Concept } & \multicolumn{1}{c|}{ Applications } \\
\hline Logic Gates & $\begin{array}{l}\text { Door control, lawn sprinkler systems, computers, gaming systems, mobile phones, } \\
\text { cameras, smoke sensors, two-way light switches, robots, automobiles, prosthetic } \\
\text { limbs, plastic molding, circuit breakers }\end{array}$ \\
\hline $\begin{array}{l}\text { Temperature } \\
\text { monitoring sys- } \\
\text { tem }\end{array}$ & $\begin{array}{l}\text { Automated car wash system, habitat for zoo animals, art museum to preserve artifacts, } \\
\text { weather prediction, firefighting robots, hospitals, car interiors, refrigerator }\end{array}$ \\
\hline Microcontroller & $\begin{array}{l}\text { Anti-lock braking system, monitor usage and save energy, assembly automation, au- } \\
\text { tomobile engine control system, television, camera, cellular phone, small scale compu- } \\
\text { tation, motion sensing flood lights }\end{array}$ \\
\hline
\end{tabular}

\section{Student Perception Feedback}

In addition to evaluating student learning through exam performance assessments, formative assessment has also been conducted through the semester in both the experimental groups. During the first day of class, an orientation session on collaborative learning was conducted, and students were introduced to various forms of learning and their respective strategies. Five weeks into the semester, after students were exposed to the presented modified flipped learning model and a first mid-term examination, a formative mid-semester feedback assessment was conducted. During this assessment session, students were asked to form into a small group and requested to identify strengths of the course that are helping them learn, and provide an example for each. Group responses were organized by topic, prioritized by the number of similar responses, and summarized in Table 9.

This practice of collecting, interpreting, and responding to student evaluation feedback in a timely manner (Gillespie \& Robertson, 2010), has been instrumental in providing the course instructor 
and students information on how learning is occurring and what can be done to enhance learning through the remainder of the course session. This positive outcome of conducting mid-semester feedback for improved student learning is consistent with the research study (Finelli, Ott, Gottfried, Hershock, O'Neal, \& Kaplan, 2011) which found that consultations based on student feedback sessions resulted in the greatest overall impact in a variety of engineering settings for instructors of different experiences. Further, as an open-ended survey typically does not provide profound feedback on the diverse instructional elements of the modified flipped course, a perception survey was also provided during mid-semester and end-of-semester as presented in Table 10. Evaluated on a Likert scale of 1-4 (1-Strongly Disagree, 4- Strongly Agree), these statements are articulated to evaluate how each instructional element contributed to student learning.

Table 9. Mid-Semester Feedback Survey Responses from the Experimental Groups $(\mathrm{n}=10$ groups, group size of 2-6)

\begin{tabular}{|c|c|c|}
\hline $\begin{array}{c}\text { Number } \\
\text { of Group } \\
\text { Responses }\end{array}$ & $\begin{array}{l}\text { Strength } \\
\text { "List major strengths of the course that } \\
\text { are helping you learn" }\end{array}$ & $\begin{array}{l}\text { Examples } \\
\text { "Please explain briefly or give an example } \\
\text { for each strength" }\end{array}$ \\
\hline 5 & $\begin{array}{l}\text { Makes adjustments according to our needs; } \\
\text { willingness to review and go over trouble } \\
\text { areas; thoroughly answered questions; he } \\
\text { asks what we have trouble with; slows down } \\
\text { when he needs to }\end{array}$ & $\begin{array}{l}\text { Spends more time on the topics we struggle } \\
\text { with; makes sure students understand mate- } \\
\text { rial }\end{array}$ \\
\hline 5 & $\begin{array}{l}\text { Laid back classroom; professor is open to } \\
\text { questions; class is open, comfortable class- } \\
\text { room environment }\end{array}$ & $\begin{array}{l}\text { Open to all questions; easy to talk to, nice } \\
\text { guy }\end{array}$ \\
\hline 4 & $\begin{array}{l}\text { Review and sample exam; study guide/pre- } \\
\text { exam; test review }\end{array}$ & $\begin{array}{l}\text { Although the real exam was much more } \\
\text { difficult than the sample exam; made study- } \\
\text { ing easier }\end{array}$ \\
\hline 4 & Videos; video for pre-lecture are beneficial & $\begin{array}{l}\text { Video examples of every topic; interesting } \\
\text { and helpful; gives a brief overview of lesson }\end{array}$ \\
\hline 4 & Handouts; learn by doing; handout packets & $\begin{array}{l}\text { Go through examples of each topic in class; } \\
\text { in-class "worksheets"; useful study tool }\end{array}$ \\
\hline 3 & Blackboard updates & Students know what is going on in class \\
\hline 2 & Post-lecture quizzes & Checks understanding of lesson \\
\hline 2 & Organization; pace & $\begin{array}{l}\text { Blackboard and document repository; goes } \\
\text { fast through easy material }\end{array}$ \\
\hline 2 & $\begin{array}{l}\text { Teaching style; the information is well cov- } \\
\text { ered }\end{array}$ & $\begin{array}{l}\text { Make sure we know the material; the infor- } \\
\text { mation presented is explained thoroughly }\end{array}$ \\
\hline 2 & $\begin{array}{l}\text { Willing to work with students; always asks } \\
\text { for feedback }\end{array}$ & Allows make-up tests and quizzes \\
\hline 2 & Hands-on activities & $\begin{array}{l}\text { The labs showed how course concepts con- } \\
\text { nect together }\end{array}$ \\
\hline
\end{tabular}

Note: Single group responses on various topics are not included.

Responses for these open-ended assessments clearly demonstrate that students easily adapted to this modified flipped model. Firstly, students acknowledged the dynamic nature of the class, whereby minor changes have been implemented in a timely fashion in response to identified learning needs. This was evident through responses from a majority of student groups identifying 
this characteristic as the major strength of the model and providing a mean perception score of 3.50 and 3.52 during mid- and end-of-semester in Table 10.

Table 10. Student perceptions to instructional elements in the modified flipped course

\begin{tabular}{|c|c|c|c|c|c|c|}
\hline $\begin{array}{l}\mathbf{N} \\
\mathbf{0}\end{array}$ & $\begin{array}{c}\text { Alignment } \\
\text { with learning } \\
\text { activity in } \\
\text { Fig. } 4\end{array}$ & Statement & $\begin{array}{l}\text { Mid- } \\
\text { Semes- } \\
\text { ter }\end{array}$ & $\begin{array}{l}\text { End- } \\
\text { Semes- } \\
\text { ter }\end{array}$ & $\begin{array}{c}\text { t- } \\
\operatorname{scor} \\
\text { e }\end{array}$ & $\begin{array}{c}\text { p- } \\
\text { val- } \\
\text { ue }\end{array}$ \\
\hline 1 & $\mathrm{~L}_{1}$ & $\begin{array}{l}\text { The third-party videos (e.g., TED, YouTube) } \\
\text { were effective in introducing me to techno- } \\
\text { logical advancements in engineering }\end{array}$ & $\begin{array}{c}3.50 \\
(0.78)\end{array}$ & $\begin{array}{c}3.34 \\
(0.70)\end{array}$ & 0.69 & 0.49 \\
\hline 2 & $\mathrm{~L}_{1}, \mathrm{~L}_{2}, \mathrm{~L}_{8}, \mathrm{~L}_{10}$ & $\begin{array}{l}\text { The technology methods used are easy to } \\
\text { access }\end{array}$ & $\begin{array}{c}3.83 \\
(0.38)\end{array}$ & $\begin{array}{l}3.73 \\
(0.45)\end{array}$ & 0.75 & 0.45 \\
\hline 3 & $\mathrm{~L}_{2}$ & $\begin{array}{l}\text { The pre-lecture videos helped prepare me to } \\
\text { learn course content }\end{array}$ & $\begin{array}{c}3.44 \\
(0.78)\end{array}$ & $\begin{array}{c}3.08 \\
(0.87)\end{array}$ & 1.37 & 0.17 \\
\hline 4 & $\mathrm{~L}_{2}$ & $\begin{array}{l}\text { The pre-lecture quiz helped prepare me to } \\
\text { learn course content }\end{array}$ & $\begin{array}{l}3.55 \\
(0.51)\end{array}$ & $\begin{array}{c}3.26 \\
(0.67)\end{array}$ & 0.52 & 0.13 \\
\hline 5 & $\mathrm{~L}_{3}, \mathrm{~L}_{4}, \mathrm{~L}_{5}, \mathrm{~L}_{6}$ & $\begin{array}{l}\text { The interactive discussion style helped me to } \\
\text { learn course content }\end{array}$ & $\begin{array}{c}3.5 \\
(0.78)\end{array}$ & $\begin{array}{c}3.52 \\
(0.59)\end{array}$ & 0.09 & 0.92 \\
\hline 6 & $\mathrm{~L}_{4}, \mathrm{~L}_{5}, \mathrm{~L}_{6}, \mathrm{~L}_{7}$ & $\begin{array}{l}\text { The in-class handouts helped me learn in this } \\
\text { class }\end{array}$ & $\begin{array}{c}3.94 \\
(0.23)\end{array}$ & $\begin{array}{c}3.82 \\
(0.38)\end{array}$ & 0.78 & 0.24 \\
\hline 7 & $\mathrm{~L}_{5}, \mathrm{~L}_{6}$ & $\begin{array}{l}\text { The classroom seating arrangements promot- } \\
\text { ed a positive learning environment }\end{array}$ & $\begin{array}{l}3.33 \\
(0.97)\end{array}$ & $\begin{array}{c}3.21 \\
(0.90)\end{array}$ & 0.41 & 0.68 \\
\hline 8 & $\mathrm{~L}_{6}, \mathrm{~L}_{9}, \mathrm{~L}_{10}$ & I can identify the practical applications of DC & $\begin{array}{c}3.33 \\
(0.48)\end{array}$ & $\begin{array}{c}3.30 \\
(0.70)\end{array}$ & 0.15 & 0.87 \\
\hline 9 & $\mathrm{~L}_{5}, \mathrm{~L}_{6}, \mathrm{~L}_{9}, \mathrm{~L}_{10}$ & $\begin{array}{l}\text { The collaborative activities have helped me } \\
\text { increase my interpersonal skills }\end{array}$ & $\begin{array}{c}3.44 \\
(0.51)\end{array}$ & $\begin{array}{c}3.17 \\
(0.63)\end{array}$ & 0.86 & 0.14 \\
\hline 10 & $\mathrm{~L}_{6}, \mathrm{~L}_{7}, \mathrm{~L}_{10}$ & $\begin{array}{l}\text { I am confident that I can extrapolate the theo- } \\
\text { retical concepts learned in this class to other } \\
\text { subjects in higher classes }\end{array}$ & $\begin{array}{l}3.27 \\
(0.46)\end{array}$ & $\begin{array}{c}3.26 \\
(0.54)\end{array}$ & 0.06 & 0.95 \\
\hline 11 & $\begin{array}{l}\mathrm{L}_{5}, \mathrm{~L}_{6}, \mathrm{~L}_{8}, \mathrm{~L}_{9} \\
\mathrm{~L}_{10}\end{array}$ & $\begin{array}{l}\text { I am confident that I can extrapolate the quan- } \\
\text { titative reasoning skills learned in this class to } \\
\text { other subjects in higher classes. }\end{array}$ & $\begin{array}{c}3.38 \\
(0.50)\end{array}$ & $\begin{array}{c}3.30 \\
(0.47)\end{array}$ & 0.52 & 0.6 \\
\hline 12 & $\mathrm{~L}_{9}, \mathrm{~L}_{10}$ & $\begin{array}{l}\text { The hands-on activities increased my } \\
\text { knowledge of real-world applications of DC }\end{array}$ & $\begin{array}{l}3.77 \\
(0.76)\end{array}$ & $\begin{array}{l}3.65 \\
(0.48)\end{array}$ & 0.61 & 0.54 \\
\hline 13 & $\mathrm{~L}_{9}, \mathrm{~L}_{10}$ & $\begin{array}{l}\text { The hands-on activities helped me to better } \\
\text { understand course concepts }\end{array}$ & $\begin{array}{c}3.61 \\
(0.50)\end{array}$ & $\begin{array}{c}3.43 \\
(0.78)\end{array}$ & 0.85 & 0.4 \\
\hline 14 & $\mathrm{~L}_{4}, \mathrm{~L}_{5}, \mathrm{~L}_{7}, \mathrm{~L}_{10}$ & $\begin{array}{l}\text { The hands-on activities are well aligned with } \\
\text { coursework }\end{array}$ & $\begin{array}{c}3.38 \\
(0.50)\end{array}$ & $\begin{array}{c}3.26 \\
(0.75)\end{array}$ & 0.58 & 0.56 \\
\hline 15 & $\mathrm{~L}_{5}, \mathrm{~L}_{6}, \mathrm{~L}_{9}$ & $\begin{array}{l}\text { I was more engaged in this class compared to } \\
\text { other classes }\end{array}$ & $\begin{array}{c}3.44 \\
(0.78)\end{array}$ & $\begin{array}{c}3.30 \\
(0.63)\end{array}$ & 0.63 & 0.52 \\
\hline
\end{tabular}

Note: Cell entities are mean, standard deviation (in parentheses)

The second major strength identified was the online preview of lectures. Students stated that these pre-lecture videos helped them gain an understanding of course material and effectively prepared them for the interactive classroom. These short (less than 10 minutes each) and informative vide- 
os have been helpful to the students as they provided an opportunity to review the course content multiple times, at their own pace. The positive perceptions of this learning activity are clearly evident in Table 10 through the high scores of 3.83 and 3.73 during mid- and end-of-semester. The TED talks focused on the technological advancements in engineering at the beginning of the semester and moved towards non-technical such as crowdsourcing, and graduate school through the end of the course semester. Accordingly, these were also ranked well with scores of 3.50 and 3.34 reported in the mid- and end-of-semester data in Table 10. Additionally, requiring students to watch TED talks and further engaging in a dialogue during class fostered the rapport between the instructor and the students.

The pre-lecture quiz was used as a formative assessment by the instructor to assess student learning, so as to either revisit or enhance important content during in-class learning activities. At the same time, the benefit to the students was that it provided a pre-exposure to course content and served as an iterative self-assessment tool to facilitate the enhancement of knowledge retention at their own pace. Accordingly, while the students perceived this as an important activity in the beginning of the semester with a score of 3.55, some felt that it was not quite efficient and provided an average score of 3.26 at the end of the semester. As the pre-lecture quizzes were designed to provide a preview of course topics, but not replace lectures, this reduction (less than one standard deviation) of a mean score was acceptable. This is consistent with the findings of Bishop and Verleger (2013), which indicate students prefer live in-person lectures to video lectures, for better preparation.

During the in-class session, in order to ascertain that students are focused on solving problems, and not merely copying the instructor's notes from the whiteboard, handouts with a series of problems were provided in each class. These handouts were found to be very useful and students worked individually and in groups, whereby they could discuss strategies and compare notes. This learning activity has been widely accepted by the students as evident through the high mean perception score of 3.94 and 3.82 during mid- and the end-of-the-semester in Table 10. In order to improve classroom interactions, several different seating arrangements have been implemented through the semester. Empirical observations have shown that students were receptive of this method through high engagement in classroom discussions, addressing their classmates, and asking questions during class. It is worth noting that the "comfortable classroom environment" is also identified as a strength in Table 9, as it allows for collaborative learning through flexible seating arrangements and dynamic group interaction.

To improve student understanding and engage students in course concepts, several collaborative learning activities such as group problem solving and think-pair-share strategies have been regularly used. The implementation of these strategies improved the student engagement and rate of student learning, resulting in the introduction of additional course content. Further, students stated that they did not feel stressed, but felt the class was "laid back" as in Table 9, which provided ample opportunity to ask questions and to learn more effectively. Finally, students commented that they were more engaged in this course than others and that they appreciated "learning by doing" and hands-on design activities, as they were able to better understand how multiple concepts worked together to solve real-time model problems. While it is important that the students perceived the hands-on activities as valuable learning exercises, it is especially important that the students recognized that learning activities are aligned well with in-class and outside-of-class activities or coursework (e.g., "The labs showed us how course concepts connected together," Table 9). This perception of alignment reinforces the value of making instructional design framework elements transparent to the students and serves to confirm the instructor continued to align instructional design framework elements for the duration of the course (e.g., 3.38 mid-term response and 3.26 end of semester response, Table 10). 
The post-lecture quiz was used as a summative tool for assessment of student learning, and, accordingly, constituted a significant portion (15\%) of the course grade. As this online quiz provides an iterative self-assessment tool to improve understanding of course content, students were receptive of this learning activity and also identified it as a strength in Table 9. It is worth noting that, in addition to relatively similar mean scores between mid-semester and end-of-semester, students also stated that they would enroll in a high-level engineering class that is taught similarly. In light of recent, related research (Freeman et al., 2014), this positive response could be attributed to the interactive discussion style that has been highly encouraged during class, timely feedback provided on learning through pre-lecture and post-lecture quiz, hands-on design activities to reinforce knowledge of real-world applications of digital circuits, and introduction of technological advancements in the classroom. While some mean scores reduced through end-ofsemester, a comparison of their difference to the respective standard deviations shows that they are certainly in an acceptable range.

Table 11. End of Semester Student Opinion Scores

\begin{tabular}{|c|c|c|c|c|c|c|}
\hline \multirow[b]{2}{*}{ Statement } & \multicolumn{3}{|c|}{ Study-01 } & \multicolumn{3}{|c|}{ Study-02 } \\
\hline & $\begin{array}{c}\text { Con- } \\
\text { trol }\end{array}$ & $\begin{array}{l}\text { Experi- } \\
\text { mental }\end{array}$ & $\begin{array}{c}\text { Differ- } \\
\text { ence }\end{array}$ & Control & $\begin{array}{l}\text { Experi- } \\
\text { mental }\end{array}$ & $\begin{array}{c}\text { Differ- } \\
\text { ence }\end{array}$ \\
\hline $\begin{array}{l}\text { Instructor's teaching helped me } \\
\text { learn }\end{array}$ & $\begin{array}{l}3.37 \\
(0.74)\end{array}$ & $\begin{array}{c}3.79 \\
(0.41)\end{array}$ & 0.42 & $\begin{array}{c}3.58 \\
(0.49)\end{array}$ & $\begin{array}{l}3.94 \\
(0.23)\end{array}$ & 0.36 \\
\hline $\begin{array}{l}\text { Instructor treated students with } \\
\text { respect }\end{array}$ & $\begin{array}{l}3.58 \\
(0.75)\end{array}$ & $\begin{array}{l}3.86 \\
(0.35)\end{array}$ & 0.28 & $\begin{array}{l}3.81 \\
(0.39)\end{array}$ & $\begin{array}{l}3.94 \\
(0.23)\end{array}$ & 0.13 \\
\hline $\begin{array}{l}\text { Instructor was accessible to stu- } \\
\text { dents }\end{array}$ & $\begin{array}{l}3.37 \\
(0.74)\end{array}$ & $\begin{array}{c}3.71 \\
(0.45)\end{array}$ & 0.34 & $\begin{array}{l}3.12 \\
(0.93)\end{array}$ & $\begin{array}{l}3.82 \\
(0.51)\end{array}$ & 0.7 \\
\hline Instructor organized course well & $\begin{array}{l}3.32 \\
(0.86)\end{array}$ & $\begin{array}{l}3.57 \\
(0.50)\end{array}$ & 0.25 & $\begin{array}{c}3.38 \\
(0.68)\end{array}$ & $\begin{array}{l}3.88 \\
(0.32)\end{array}$ & 0.5 \\
\hline $\begin{array}{l}\text { Instructor presented course mate- } \\
\text { rial well }\end{array}$ & $\begin{array}{c}3.37 \\
(0.93)\end{array}$ & $\begin{array}{l}3.57 \\
(0.62)\end{array}$ & 0.2 & $\begin{array}{c}3.5 \\
(0.64)\end{array}$ & $\begin{array}{l}3.88 \\
(0.32)\end{array}$ & 0.38 \\
\hline Instructor seemed well prepared & $\begin{array}{l}3.42 \\
(0.67)\end{array}$ & $\begin{array}{l}3.86 \\
(0.35)\end{array}$ & 0.44 & $\begin{array}{l}3.65 \\
(0.55)\end{array}$ & $\begin{array}{l}3.94 \\
(0.23)\end{array}$ & 0.29 \\
\hline $\begin{array}{l}\text { Instructor was enthusiastic about } \\
\text { subject }\end{array}$ & $\begin{array}{c}3.53 \\
(0.68)\end{array}$ & $\begin{array}{l}4.00 \\
(0.00)\end{array}$ & 0.47 & $\begin{array}{l}3.65 \\
(0.48)\end{array}$ & $\begin{array}{l}4.00 \\
(0.00)\end{array}$ & 0.35 \\
\hline Overall instructor effectiveness & $\begin{array}{c}3.35 \\
(0.84)\end{array}$ & $\begin{array}{c}3.83 \\
(0.37)\end{array}$ & 0.48 & $\begin{array}{c}3.54 \\
(0.58)\end{array}$ & $\begin{array}{l}3.94 \\
(0.24)\end{array}$ & 0.4 \\
\hline
\end{tabular}

Note: Cell entities are mean, standard deviation (in parentheses)

In addition, pursuant to university policies, an end-of-semester student opinion survey was also conducted to seek students' perceptions of the instructor's teaching effectiveness, as presented in Table 11. This data clearly shows that students responded strongly for every statement in the modified flipped course. Specifically, significant differences were observed in accessibility of the instructor, his/her preparedness, and enthusiasm about the subject. This could be partially attributed to the mid-semester assessment conducted to identify methods of improving student learning. However, in the modified flipped course, the instructor was able to spend most of the class time interacting with students, helped them understand the concepts through one-on-one instruction, and engaged them in design activities. This led students to perceive that instructor 
was more accessible in the modified flipped model than the traditional model. In addition, students perceived a greater instructor's enthusiasm in the modified flipped model, which aligns with increased student engagement. This increased interaction between instructor and students is an essential ingredient for establishing strong faculty-student rapport, as students' progress further in the engineering program. Finally, student perceptions of self-efficacy and confidence in their abilities to extrapolate concepts and apply skills to subsequent courses (Table 10), may be attributed to the development of positive student-faculty rapport in combination with the variety of learning activities and assessments, as observed by Micari and Pazos (2012) and Vogt (2008).

\section{Discussion}

The high attrition rate (Felder, 2012) combined with relatively low enrollment in engineering has resulted in increased pressure for engineering educators to increase the first-year retention rate while at the same time increase student skillset required to hold pace with technology progressions. By leveraging the technological advancements and implementing evidenced-based pedagogy, the instructional design framework approach provides a high-impact and economical method (no active learning spaces, no expensive hardware required) by which student interest and learning could be increased and additional course content could be introduced in a timeconstrained setting. Results from the multiple-pedagogical model were encouraging despite identified challenges and offer promising results for adoption in a first-year engineering curriculum. The results were particularly relevant, due to the limited evidence demonstrating successfully flipped course framework in first-year engineering courses, as opposed to upper-division engineering courses (Bishop \& Verleger, 2013; Mason et al., 2013).

First and foremost, the overarching "significant learning goal" (Fink, 2013) for the course was to introduce students to the field of computer and electrical engineering. This significant learning goal was identified through the utilization of Wiggins's (1998) "backward design" approach to course enhancement, which facilitated the purposeful alignment of essential instructional design factors. Based on student responses, $100 \%$ of the experimental group stated that they "would enroll in a higher-level engineering class that is taught similarly" and more than $60 \%$ responded that "because of completing this course, [their] interest in pursuing a degree in computer or electrical engineering has increased." These data are particularly encouraging to the field of engineering in light of the fact these students were introduced to concepts such as digital circuits and discrete mathematics-based engineering concepts, which are traditionally offered in upper-level courses.

Student responses also supported additional significant learning goals such as enhanced interpersonal skills $(100 \%)$ resulting from collaborative course activities. This is consistent with prior research, which finds collaborative course activities, as opposed to competitive course activities, enhance interpersonal skills (Prince, 2004). These collaborative activities also provided opportunities for enhanced critical thinking and problem-solving skills essential for success in the field of engineering and competing in a global economy While it is often challenging to effectively analyze students' critical thinking and problem-solving abilities, researchers contend students who engage in collaborative, problem-solving activities tend to retain concepts longer and develop enhanced critical thinking and problem solving skills (Freeman et al., 2014; Prince, 2004). These skills are vital to promoting student persistence throughout an engineering program and, more importantly, to employers who have identified communication and critical thinking skills to be among the skills most important to employers (Hart Research Associates, 2015).

Additionally, students reported that combination of teaching and learning activities, such as interactive discussion and diverse in-class and outside-of-class instructional elements (e.g., pre-class quizzes, pre-class videos, handouts, post-class quizzes, exams, and hands-on activities) helped them learn better. This strategic combination of teaching and learning activities, which were purposefully aligned with CLOs, facilitated student achievement (Fink, 2013; Reeves, 2006; Wig- 
gins, 1998). Further, the modified flipped model implemented in a traditional classroom with no formal active learning spaces allowed for dynamically modifying class seating arrangements for hands-on and collaborative work in a cost-effective manner utilizing technology available at most institutions (e.g., video, learning management systems, podcasts). Upon review of the alignment of the instructional design elements, data suggests that the modified flipped course framework allowed the instructor to increase course content, adding timely relevant concepts beyond the traditional course offering. These results, while not statistically significant, do suggest that a combination of traditional lectures, active learning, and collaborative learning through a modified flipped model allows for enrichment of course content, without posing a significant learning burden on the students, time commitment from the instructor, or a financial burden on the university.

Initially, some students in the experimental groups were skeptical about the proposed methods of learning, but they subsequently changed their perceptions through the semester. Overall, the modified flipped course framework proved to be very efficient in bringing the students together to work on common goals and improved their technical skills in the first-year engineering curriculum. It can be broadly stated that offering a first-year engineering course in modified flipped model has several advantages. It (i) offers a technology integrated learning platform; (ii) enables swift and periodic communication between student and faculty, thus enriching the rapport; (iii) frees classroom time for dynamic and interactive collaborative activities to reinforce learning without sacrificing course content; (iv) is more activity-oriented than lecture oriented, promoting progressive learning; (v) allows students to learn at their own pace and become self-learners; (vi) provides a collaborative learning environment where students can discuss, collaborate, and present their findings more effectively and efficiently; and most importantly (vii) allows for flipping a first-year engineering course within a low-budget without necessitating active learning spaces.

These student responses suggest that, by utilizing a three-step instructional design framework (examine situational factors, integrate CLOs, and ensure alignment of instructional design elements), student learning could be increased. More specifically, by examining the situational factors such as learner characteristics, the instructor was able to anticipate knowledge gaps. This allowed for the design of learning activities in a first-year engineering course that builds positive student-faculty rapport and highly engaged students. Finally, by ensuring alignment of instructional design elements, student performance on exams improved. The student responses to the mid- and end-of-semester perception survey further confirm the influences of the situational factors on the instructional design of a modified flipped course.

\section{Conclusion}

This article presented an instructional design framework through which a first-year engineering class has been redesigned to improve student learning. First, identifying evidence-based, effective teaching strategies, such as requiring students to watch instructor recorded, online videos and take a pre-lecture quiz prior to class, pre-exposed students to the subject matter to be discussed and applied during class. Further, this method allowed the instructor to identify concepts where students were having difficulty and extend additional focus on the same during class. Timely assessment of student learning through post-lecture quizzes helped the students self-assess their academic progress, improved their self-efficacy, and increased overall participation in the classroom. This method reinforced students' conceptual understanding and supplemented their learning. Second, the timely implementation of hands-on design activities combined with extrapolation of course concepts to real-world situations helped increased students' critical thinking skills.

The technology aids utilized in this model included a tablet device such as Bamboo Capture Pad to record the pre-lecture videos, an online learning management system such as Blackboard to post the lecture notes and collect data from pre- and post-lecture quizzes, and a few laboratory supplies such as microcontrollers, logic gates, and testing equipment. The majority of these aids, 
with the exception of the tablet device, are available for instructors in a typical engineering program and can be easily implemented in their respective classrooms. However, it has to realized that care should be taken while preparing these videos to ensure that they are not too long as students might lose interest quickly. Through data analytics, it was found that students are comfortable watching several videos with a duration of less than 10 minutes each.

Increasing first-year student awareness of different projects and career opportunities in engineering is critical to the future of the field. Thus, to spark student interest, each week they were required to watch a TED talk prior to class. During the class period, the students and instructors engaged in an interactive discussion on the topics presented and their implications. This helped the students obtain a broader sense of engineering challenges and opportunities available beyond the academic environment.

Overall, by examining situational factors, revising course learning objectives, and implementing instructional design elements, a low-cost modified flipped model has been developed and implemented. The presented model has resulted in improved students' awareness of electrical and computer engineering applications and has reinforced their critical thinking and problem-solving skills through team-based collaborative and active learning activities. This study provided an evidential foundation to guide the future research of the design of effective learning environments in low-cost engineering classrooms.

\section{References}

Baepler, P., Walker, J. D., \& Driessen, M. (2014). It's not about seat time: Blending, flipping, and efficiency in active learning classrooms. Computers \& Education, 78, 227-236.

Bain, K. (2004). What the best college teachers do. Harvard University Press.

Berrett, D. (2012, February 19). How 'flipping' the classroom can improve the traditional lecture. The Chronicle of Higher Education. Retrieved September 19, 2016, from http://chronicle.com/article/HowFlipping-the-Classroom/130857

Bishop, J. L., \& Verleger, M. A. (2013). The flipped classroom: A survey of the research. Proceedings of $120^{\text {th }}$ American Society for Engineering Education Annual Conference \& Exposition.

Canfield, S., Ghafoor, G., \& Abdelrahman, M. (2012). Enhancing the programming experience for firstyear engineering students through hands-on integrated computer experiences. Journal of STEM Education, 13(4), 43-54.

Cotner, S., Loper. J., Walker. J. D., \& Brooks, D. C. (2013). "It's not you, it's the room"- Are the high-tech, active learning classrooms worth it? Journal of College Science Teaching, 82-88.

Dal, M. (2013). Teaching electric drives control course: Incorporation of active learning into the classroom. IEEE Transactions on Education, 56(4), 459-469.

Danielson, J., Preast, V., Bender, H., \& Hassall, L. (2014). Is the effectiveness of lecture capture related to teaching approach or content type? Computers \& Education, 72, 121-131.

Felder, R. M. (2012). Engineering education: A tale of two paradigms. In B. McCabe, M. Pantazidou, and D. Phillips [Eds.], Shaking the foundations of geo-engineering education (pp. 9-14). Leiden: CRC Press.

Finelli, C. J., Ott, M., Gottfried, A. C., Hershock, C., O’Neal, C., \& Kaplan, M. (2011). Utilizing instructional consultations to enhance the teaching performance of engineering faculty. Journal of Engineering Education, 97(4), 397-412.

Fink, D. L. (2013). Creating significant learning experiences: An integrated approach to designing college courses. San Francisco, CA: Jossey-Bass 
Freeman, S., Eddy, S. L., McDonough, M., Smith, M. K., Okoroafor, N., Jordt, H., \& Wenderoth, M. P. (2014). Active learning increases student performance in science, engineering, and mathematics. Proceedings of the National Academy of Sciences of the United States of America, 111(23), 8410-8415.

Ganago, A., \& Liao, H. (2013). Student learning in a required electrical engineering (EE) course for nonEE majors: Perception of values for future work in multidisciplinary teams. Proceedings of American Society for Engineering Education Annual Conference and Exposition.

Gillespie, K. J., \& Robertson, D. L. (2010). A guide to faculty development (2nd ed.). Jossey-Bass.

Hart Research Associates. (2015). Falling short? College learning and career success. Selected Findings from Online Surveys of Employers and College Students.

Hattie, J. (2012). Visible learning for teachers. Routledge.

Hong, B. S., \& Shull, P. J. (2010). A retrospective study of the impact faculty dispositions have on undergraduate engineering students. College Student Journal, 44(2), 266-278.

Jensen, E. (2008). Brain-based learning. Corwin Press.

Kim, G. J., Patrick, E. E., Srivastava, R., \& Law, M. E. (2014). Perspective on flipping circuits I. IEEE Transactions on Education, 57(3), 188-192.

Koehler, M. J., \& Mishra, P. (2008). Handbook of technological pedagogical content knowledge (TPCK) for educators. Routledge.

Koproske, C. (2012). The promise and perils of innovation: Part I. Education Advisory Board.

Krathwohl, D. R. (2002). A revision of Bloom's taxonomy: An overview. Theory into Practice, 41(4), 212.

Lawler, P. A., \& King, K. P. (2000). Planning for effective faculty development. Malabar, FL: Krieger Publishing Company.

Lodaya, H. (2013). Flipped classrooms can improve STEM education. STEM Wire. Retrieved September 19, 2016, from http://stemwire.org/2013/06/06/flipped-classrooms-can-improve-stem-education

Mason, G. S., Shuman, T. R., \& Cook, K. E. (2013). Comparing the effectiveness of an inverted classroom to a traditional classroom in an upper division engineering course. IEEE Transactions on Education, 56(4), 430-435.

Micari, M., \& Pazos, P. (2012). Connecting to the professor: Impact of the student-faculty relationship in a highly challenging course. College Teaching, 60(2), 41-47.

Nashash, H. A., \& Gunn, C. (2013). Lecture capture in engineering classes: Bridging gaps and enhancing learning. Journal of Educational Technology \& Society, 16(1), 69-78.

Prince, M. (2004). Does active learning work? A review of the research. Journal of Engineering Education, 93(3), 223-231.

Reeves, T. C. (2006). How do you know they are learning? The importance of alignment in higher education. International Journal of Learning Technology, 2(4), 294-309. Retrieved September 19, 2016, from http://net.educause.edu/ir/library/pdf/eli08105a.pdf

Reisslein, M., Tylavsky, D., Matar, B., Seeling, P., \& Reisslein, J. (2007). Active and cooperative learning in a freshman digital design course: Impact on persistence in engineering and student motivational orientation. Proceedings of IEEE Frontiers in Education, S4A-1-S4A-6.

Roppel, T. A., Hung, J. Y., Wentworth, S. W., \& Hodel, A. S. (2000). An interdisciplinary laboratory sequence in electrical and computer engineering: Curriculum design and assessment results. IEEE Transactions on Education, 43(2), 143-152.

Rosa-Pohl, D. G., Long, S. A., \& Goodwin, C. (2013). Introduction to digital logic project in a first-year honors engineering course. Proceedings of $120^{\text {th }}$ American Society for Engineering Education Annual Conference and Exposition. 
Sahin, S., \& Isler, Y. (2013). Microcontroller-based robotics and SCADA experiments. IEEE Transactions on Education, 56(4), 424-429.

Shelton, C. (2014). Virtually mandatory: A survey of how discipline and institutional commitment shape university lecturers' perceptions of technology. British Journal of Educational Technology, 45(4), 748759.

Singer, S., Nielsen, N., \& Schweingruber, H. (2012). Discipline-based education research: Understanding and improving learning in undergraduate science and engineering. Washington, DC: The National Academies Press.

Smith, S. (2015). CMU's active learning classrooms improve STEM students' learning. Central Michigan University News, Mount Pleasant, MI. Accessed September 19, 2016, at www.cmich.edu/news/article/Pages/active-learning-classrooms-improve-STEM-learning.aspx

Strayer, J. F. (2012). How learning in an inverted classroom influences cooperation, innovation and task orientation. Learning Environments Research, 15(2), 171-193.

Suresh, R. (2006). The relationship between barrier courses and persistence in engineering. Journal of College Student Retention: Research, Theory \& Practice, 8(2), 215-239.

Technology, Entertainment, Design. (2015). Sapling Foundation. Website www.ted.org, Last accessed: Sep 19, 2016.

Vignare, K. (2007). Review of literature. Blended learning: Using ALN to change the classroom - Will it work? In A. Picciano \& C. Dzuiban (Eds.), Blended learning: Research perspectives. Needham, MA: SLOAN-C.

Visco, D. P., \& Schaefer, D. (2015). Training engineering faculty to be educators: History, motivations and a comparison of US and international systems. Proceedings of $122^{\text {nd }}$ American Society for Engineering Education Annual Conference and Exposition.

Vogt. C. M. (2008). Faculty as a critical juncture in student retention and performance in engineering programs. Journal of Engineering Education, 97(1), 27-36.

Wiggins, G. (1998). Educational assessment: Designing assessment to inform and improve student performance. San Francisco, CA: Jossey-Bass.

Wiggins, G., \& McTighe, J. (1998). What is backward design? Understanding by design. Association for Supervision and Curriculum Development.

Yelamarthi, K., \& Drake, E. (2015). A flipped first-year digital circuits course for engineering and technology students. IEEE Transactions on Education, 58(3), 179-186.

Zappe, S., Leicht, R., Messner, J., Litzinger, T., \& Lee, H. W. (2009). Flipping the classroom to explore active learning in a large undergraduate course. Proceedings of American Society for Engineering Education Annual Conference \& Exposition. 


\section{Appendix: Student Perception Survey: Mid-Semester/End-Semester}

1. Please indicate the extent to which you agree or disagree with each of the statements below. (You may recognize some of these questions from an earlier survey; however, by sharing your responses now, at the end of the course, you will provide the instructor with a more comprehensive understanding of your learning experience.). Rank the statements below according to the following scale:

$\begin{array}{cccc}\text { Strongly Disagree } & \text { Disagree } & \text { Agree } & \text { Strongly Agree } \\ 1 & 2 & 3 & 4\end{array}$

- The third-party videos (e.g., TED, YouTube) were effective in introducing me to technological advancements in engineering

$\square 1 \quad \square 2 \quad \square 3 \quad \square 4$

- The technology methods used are easy to access
$\square 1 \quad \square 2 \quad \square 3 \quad \square 4$

- The pre-lecture videos helped prepare me to learn course content
$\square 1 \quad \square 2 \quad \square 3 \quad \square 4$

- The pre-lecture quiz helped prepare me to learn course content

$\square 1 \quad \square 2 \quad \square 3 \quad \square 4$

- The interactive discussion style helped me to learn course content
$\square 1 \quad \square 2 \quad \square 3 \quad \square 4$

- The in-class handouts helped me learn in this class

$\square 1 \quad \square 2 \quad \square 3 \quad \square 4$

- The classroom seating arrangements promoted a positive learning environment
$\square 1 \quad \square 2 \quad \square 3 \quad \square 4$

- I can identify the practical applications of DC
$\square 1 \quad \square 2 \quad \square 3 \quad \square 4$

- The collaborative activities have helped me increase my interpersonal skills
$\square 1 \quad \square 2 \quad \square 3 \quad \square 4$

- I am confident that I can extrapolate the theoretical concepts learned in this class to other subjects in higher classes
$\square 1 \quad \square 2 \quad \square 3 \quad \square 4$

- I am confident that I can extrapolate the quantitative reasoning skills learned in this class to other subjects in higher classes.
$\square 1 \quad \square 2 \quad \square 3 \quad \square 4$

- The hands-on activities increased my knowledge of real-world applications of DC
$\square 1 \quad \square 2 \quad \square 3 \quad \square 4$ 
- The hands-on activities helped me to better understand course concepts
$\square 1 \quad \square 2 \quad \square 3 \quad \square 4$

- The hands-on activities are well aligned with coursework
$\square 1$
$\square 2 \square 3 \quad \square 4$

- I was more engaged in this class compared to other classes

$\square 1 \quad \square 2 \quad \square 3 \quad \square 4$

2. What additional comments, if any, do you have about your learning experience in this course?

\section{Student Opinion Survey}

Please choose the responses to each of the following statements that BEST indicates your opinion:

$\begin{array}{cccc}\text { Strongly Disagree } & \text { Disagree } & \text { Agree } & \text { Strongly Agree } \\ 1 & 2 & 3 & 4\end{array}$

- Instructor's teaching helped me learn
$\square 1 \quad \square 2 \quad \square 3 \quad \square 4$

- Instructor treated students with respect
$\square 1 \quad \square 2 \quad \square 3 \quad \square 4$

- Instructor was accessible to students
$\square 1 \quad \square 2 \quad \square 3 \quad \square 4$

- Instructor organized course well
$\square 1 \quad \square 2 \quad \square 3 \quad \square 4$

- Instructor presented course material well
$\square 1 \quad \square 2 \quad \square 3 \quad \square 4$

- Instructor seemed well prepared
$\square 1 \quad \square 2 \quad \square 3 \quad \square 4$

- Instructor was enthusiastic about subject
$\square 1 \quad \square 2 \quad \square 3 \quad \square 4$ 
$\begin{array}{cccc}\text { Very Poor } & \text { Poor } & \text { Good } & \text { Very Good } \\ 1 & 2 & 3 & 4\end{array}$

- Overall instructor effectiveness

$\square 1 \quad \square 2 \quad \square 3 \quad \square 4$

\section{Biographies}

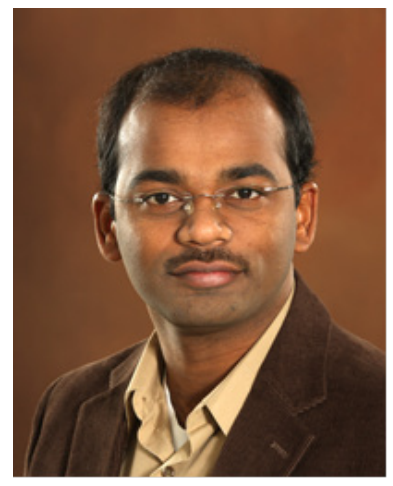

Kumar Yelamarthi received his Ph.D. and M.S degree from Wright State University in 2008 and 2004, and B.E. from University of Madras, India in 2000. He is currently an Associate Professor of Electrical \& Computer Engineering, and Assistant Director for the School of Engineering and Technology at Central Michigan University. His research interest is in the areas of Wireless Sensor Networks, Internet of Things, computer aided design tool development, assistive devices, mobile robots, applied electronics, embedded systems, and engineering education. He has published over 100 articles in archival journals and conference proceedings in these areas. He is an elected member of Tau Beta Pi engineering honor society, and Omicron Delta Kappa national leadership honor society, and a senior member of IEEE.

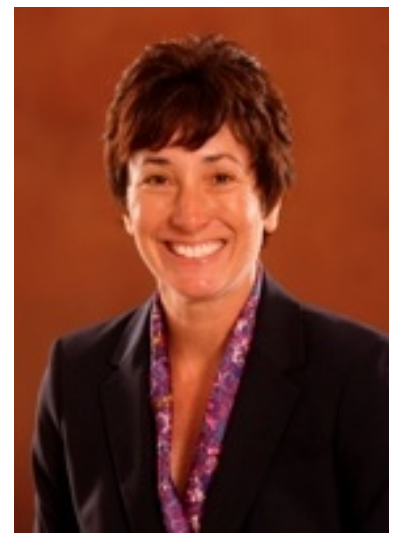

Eron Drake received her Ed.D. degree in Education with an emphasis on curriculum and instruction from Central Michigan University in 2009. She also holds an M.B.A. from Western Michigan University, Kalamazoo, MI. She is currently the Director of Academic Success at Central Michigan University College of Medicine in Mount Pleasant, MI, and has over twelve years of experience in leading instructional and faculty development programs and services. She annually conducts over 50 workshops on high-impact teaching and learning practices, provides consultations with students, faculty, departments and colleges, and presents at national and international conferences. She is a member of the Association of American Medical Colleges.

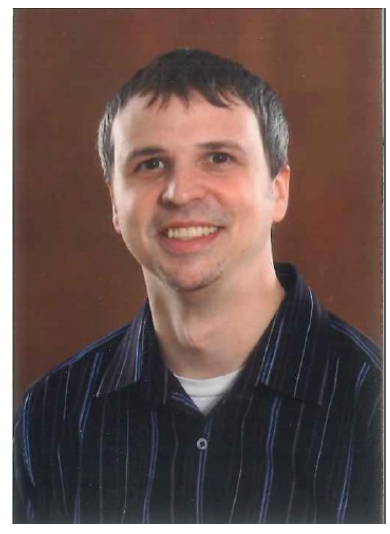

Matthew Prewett received his Ph.D. in Industrial/Organizational Psychology from the University of South Florida in 2009 and is currently an Assistant professor in the Department of Psychology at Central Michigan University. His research is broadly focused on group dynamics, creating assessments for work-related behaviors and competencies, and the acquisition of new skills through different learning and training approaches. His published research can be found in Human Performance, Computers in Human Behavior, IEEE Transactions on Systems, Man and Cybernetics, Part C: Applications and Reviews, and Medical Education. 